\title{
Leaf gas exchange and photosynthesis curves of Elymus nutans and Potentilla anserina under fencing and grazing conditions in the Qilian Mountains, Northwest China
}

\author{
LIU Junjie ${ }^{1}$, WANG Xiaoping ${ }^{2}$, GAO Yunfei ${ }^{1}$, RONG Zhanlei ${ }^{1}$, ZHANG Guangde ${ }^{1}$, WANG \\ Wenbin $^{1}$, GE Lijuan ${ }^{1}$, MAO Yahua ${ }^{1}$, GUO Zhaoxia ${ }^{1}$, ZHAO Chuanyan ${ }^{1 *}$ \\ ${ }^{1}$ State Key Laboratory of Grassland Agro-ecosystems, School of Life Sciences, Lanzhou University, Lanzhou 730000, China; \\ 2 Institute of Arid Meteorology, China Meteorological Administration, Lanzhou 730020, China
}

\begin{abstract}
Potentilla anserina L. and Elymus nutans Griseb. are dominant species in the subalpine meadows of China. Grazing is one of the most important factors that influence community structure and productivity of subalpine meadows. Understanding how grazing changes photosynthetic capability is essential for preservation and restoration of grasslands. However, information about the effects of grazing on photosynthetic capability remains inadequate. Experiments were conducted in fencing and grazing areas in the Qilian Mountains, Northwest China. The leaf gas exchange and photosynthetic curves of $P$. anserina and E. nutans were measured at different growth stages. Results showed that grazing decreased the values of leaf gas exchange parameters, such as net photosynthetic rate, stomatal conductance, transpiration rate, and intercellular $\mathrm{CO}_{2}$ concentration of $P$. anserina and E. nutans. In addition, grazing decreased the values of net photosynthetic rate-photosynthetically active radiation $\left(P_{\mathrm{N}}-\mathrm{PAR}\right)$ curve parameters, such as light-saturated net photosynthetic rate, apparent quantum efficiency, light compensation point, light saturation point, and dark respiration rate. Our results demonstrated that grazing was the primary limiting factor for photosynthesis of dominant grassland species in the study area.
\end{abstract}

Keywords: grazing; diurnal variation; gas exchange; Potentilla anserina; Elymus nutans; photosynthetic capacity

Citation: LIU Junjie, WANG Xiaoping, GAO Yunfei, RONG Zhanlei, ZHANG Guangde, WANG Wenbin, GE Lijuan, MAO Yahua, GUO Zhaoxia, ZHAO Chuanyan. 2019. Leaf gas exchange and photosynthesis curves of Elymus nutans and Potentilla anserina under fencing and grazing conditions in the Qilian Mountains, Northwest China. Journal of Arid Land, 11(3): 431-445. https://doi.org/10.1007/s40333-019-0009-6

\section{Introduction}

Plant growing in natural conditions is limited by multiple environmental factors (i.e., light, water, temperature, and nutrition) and human disturbances (i.e., grazing, land use transformation, mining, deforestation, and environmental pollution) (Guo et al., 2007; Andrew et al., 2016; Busso et al., 2016; Casazza et al., 2016). The effects of environmental factors on plant growth are mainly slow and gradual, whereas those of human activities are mainly rapid and abrupt (Chesson, 2000; Wertin et al., 2015; Humphrey et al., 2016). Grazing, an anthropogenic activity has played an important role in controlling grass growth in natural grasslands. Some researchers have reported

\footnotetext{
${ }^{*}$ Corresponding author: ZHAO Chuanyan (E-mail: nanzhr@1zb.ac.cn)

Received 2017-11-04; revised 2018-07-28; accepted 2018-09-05

(C) Xinjiang Institute of Ecology and Geography, Chinese Academy of Sciences, Science Press and Springer-Verlag GmbH Germany, part of Springer Nature 2019
} 
that heavy grazing restricts plant growth and production in grasslands (Bai et al., 2015; Strahan et al., 2015; Pulido et al., 2016), while fencing and light grazing promote the normal growth of herbage (MãLler et al., 2014; Ruizalbarran et al., 2016). On the one hand, grazing directly affects photosynthesis by eating the ground part of grass. On the other hand, grazing affects the soil physical and chemical properties (i.e., bulk density, water infiltration, soil organic matter, total nitrogen, and total phosphorus) that subsequently influence the ability of plants to assimilate photosynthate; thus, it is the major determinant of the potential productivity of grasslands (Wang et al., 2015; Ren et al., 2016).

Livestock population has increased with increasing human population growth. Thus, grazing areas have expanded worldwide and seriously degraded grasslands (Wang and Wesche, 2016; Qian et al., 2017). Grazing not only controls grassland species diversity and composition, but also affects photosynthetic characteristics of major steppe species (Chen et al., 2005; Herrero-Jáuregui and Oesterheld, 2017). Grazing restriction is a common approach for protection of grasslands, including rotational grazing and controlled grazing (Pei et al., 2008; Hu et al., 2009; Wu et al., 2010; Mekuria, 2013; Zhang et al., 2013). It is common knowledge that degraded grasslands resulting from overgrazing have been restored under five years after fencing conditions (i.e., five years of no grazing). However, studies on the difference in photosynthetic parameters of plants between under grazing and five years of fencing conditions are scarce. Potentilla anserina L. and Elymus nutans Griseb. are $\mathrm{C}_{3}$ perennial plants and the dominant species of subalpine meadows in China. They have high photosynthetic capacity and good forage quality (Xu et al., 2006, 2011; Liu et al., 2016). In addition, they have an elaborate root system and high coverage, making them be important species in reducing water and soil losses (Jiao et al., 2009; Zhao et al., 2017). Heavy grazing has significantly decreased the photosynthetic capacity of these species. However, information on the interaction between grazing and photosynthetic characteristics of these species remains limited. Therefore, this study is conducted to obtain such information by investigating the leaf gas exchange and photosynthetic curves of $P$. anserina and $E$. nutans in the subalpine meadows of China. Our objectives are (1) to compare the diurnal patterns of leaf gas exchange parameters of plants under fenzing and grazing conditions for five years; (2) to clarify the response curves of net photosynthetic rate-photosynthetically active radiation $\left(P_{\mathrm{N}}-\mathrm{PAR}\right)$ of plants under two regimes; and (3) to identify the difference in the photosynthetic capacity of plants under two regimes.

\section{Materials and methods}

\subsection{Study area and experimental design}

Our study area is located in the Tianlaochi Catchment $\left(38^{\circ} 23^{\prime} 56^{\prime \prime}-38^{\circ} 26^{\prime} 47^{\prime \prime} \mathrm{N}\right.$, 99 $\left.53^{\prime} 57^{\prime \prime}-99^{\circ} 57^{\prime} 10^{\prime \prime} \mathrm{E}\right)$ in the central region of the Qilian Mountains, China. Tianlaochi Catchment is part of the upper reaches of the Heihe River, Northwest China, and covers an area of approximately $12.8 \mathrm{~km}^{2}$ with an elevation range between 2660 and $4419 \mathrm{~m}$ a.s.l. (Fig. 1). The climate is characterized by short and warm summers and long and cold winters. Annual mean temperature ranges from $-0.6^{\circ} \mathrm{C}$ to $2.0^{\circ} \mathrm{C}$ with a maximum monthly temperature of $11.6^{\circ} \mathrm{C}$ in July and a minimum monthly temperature of $-14.5^{\circ} \mathrm{C}$ in December. The mean annual precipitation is $435.5 \mathrm{~mm}$. Precipitation mainly occurs from May to September and accounts for $89.2 \%$ of the annual precipitation. Temperature decreases and precipitation increases with increasing elevation. The combination of temperature and precipitation causes a distinct vertical distribution of plant communities. The sequence of plant communities from lower to upper is as follows: desert steppe, forest steppe, subalpine shrub, and subalpine meadow. Subalpine meadow is rich in species and dominated by $P$. anserina and $E$. nutans (Table 1). The soil is alpine gray brown soil (approximately $50 \mathrm{~cm}$ in depth) and root systems are mainly distributed at the depth of $20 \mathrm{~cm}$. The physical and chemical properties of the soil in the experimental site are shown in Table 2. Generally, the growth period of P. anserina and E. nutans is from late April to early September (Shi et al., 2010). 


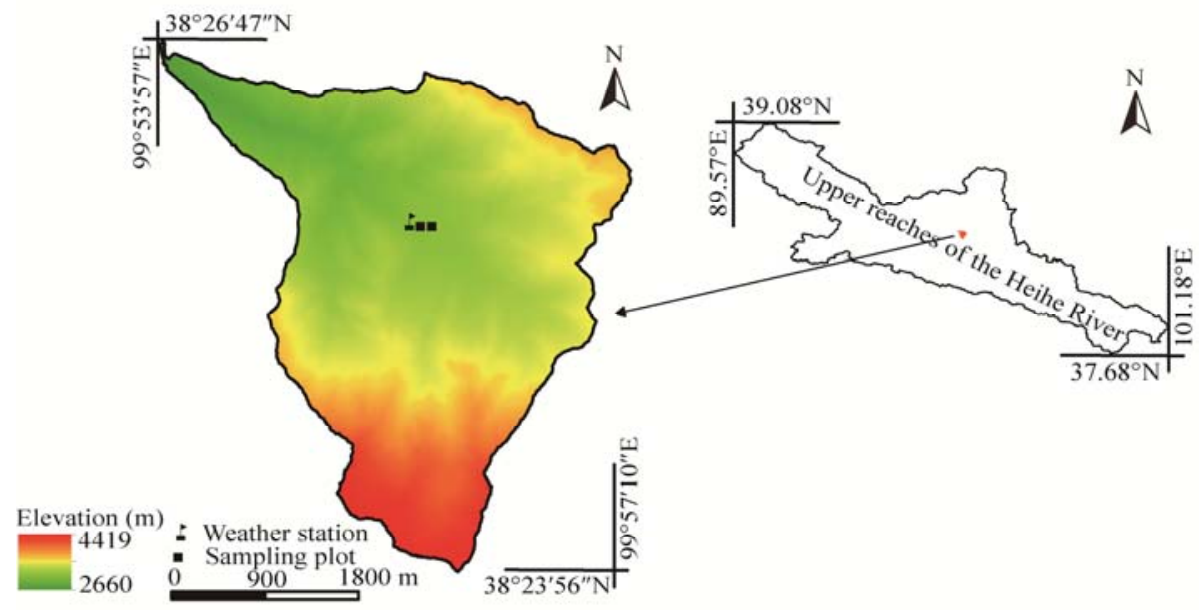

Fig. 1 Location of study area and sampling plots

Table 1 Summary of characteristics for the species selected in the experimental site

\begin{tabular}{lllllll}
\hline Species & Family & Life cycle & $\begin{array}{l}\text { Plant } \\
\text { type }\end{array}$ & $\begin{array}{l}\text { Morphological } \\
\text { characteristics }\end{array}$ & Ecology habit & Palatability \\
\hline P. anserina & Rosaeeae & Perennial & $\mathrm{C}_{3}$ & $\begin{array}{l}\text { Typical stoloniferous } \\
\text { herb }\end{array}$ & $\begin{array}{l}\text { Cold and drought resistant; } \\
\text { sciophiles }\end{array}$ & Medium \\
E. nutans & Poaceae & Perennial & $\mathrm{C}_{3}$ & Hydrophobic cluster herb & Cold resistant; heliophile & High \\
\hline
\end{tabular}

The experimental area was fenced to prevent grazing in 2012. Other areas in the subalpine meadow have been overgrazing by livestock (approximately $691 \times 10^{3}$ sheep units) for more than 30 years (Wang et al., 2014). In 2016, we selected one plot with an area of $8 \mathrm{~m} \times 12 \mathrm{~m}$ in fencing and grazing regions with a buffer zone of $10 \mathrm{~m}$ in width between two plots for protection against disturbance and the edge effect. Both plots have similar slopes and slope positions.

Table 2 Physical and chemical properties of the soil in the experimental site

\begin{tabular}{|c|c|c|c|c|}
\hline Soil property & Component & & Mean & $\begin{array}{c}\text { Coefficient of } \\
\text { variation }\end{array}$ \\
\hline \multirow{5}{*}{ Chemical property } & \multicolumn{2}{|c|}{ Soil organic matter $(\mathrm{g} / \mathrm{kg})$} & 94.67 & 0.24 \\
\hline & \multicolumn{2}{|c|}{ Soil organic carbon $(\mathrm{g} / \mathrm{kg})$} & 68.43 & 0.26 \\
\hline & \multicolumn{2}{|l|}{$\mathrm{pH}$} & 7.95 & 0.11 \\
\hline & \multicolumn{2}{|l|}{$\mathrm{C} / \mathrm{N}$} & 12.71 & 0.16 \\
\hline & \multicolumn{2}{|c|}{ Soil bulk density $(\mathrm{g} / \mathrm{cm})$} & 1.00 & 0.20 \\
\hline \multirow{6}{*}{ Physical property } & \multicolumn{2}{|l|}{ Slope $\left(^{\circ}\right)$} & 11.35 & 0.14 \\
\hline & \multicolumn{2}{|l|}{ Soil thickness (m) } & 0.44 & 0.12 \\
\hline & \multicolumn{2}{|c|}{ Soil total porosity (\%) } & 62.28 & 0.12 \\
\hline & \multirow{3}{*}{ Soil texture (\%) } & Sand & 24.31 & 0.21 \\
\hline & & Silt & 52.65 & 0.12 \\
\hline & & Clay & 23.04 & 0.11 \\
\hline
\end{tabular}

\subsection{Data collection}

Each plot was divided into six subplots $(4 \mathrm{~m} \times 4 \mathrm{~m})$. Photosynthetic parameters, including gas exchange parameters and $P_{\mathrm{N}}$-PAR response curves were measured for each subplot with six duplicates.

Gas exchange parameters were measured during one completely sunny day in each month of the growing season (i.e., June, July, and August in 2016). Three plants of each species with similar growth status were selected from the center of each subplot. One leaf was selected per 
plant. Selection criteria are leaves being newly expanded, healthy, and at the similar growing positions. The middle section of the selected leaf was measured at 1-hour intervals from 08:00 (LST) to 20:00 using a portable photosynthesis system (LI-6400, LI-COR Inc., Lincoln, NE, USA). We obtained the following gas exchange parameters, i.e., net photosynthetic rate $\left(P_{\mathrm{N}}\right)$, transpiration rate $(E)$, stomatal conductance $\left(g_{\mathrm{s}}\right)$, and intercellular $\mathrm{CO}_{2}$ concentration $\left(C_{\mathrm{i}}\right)$. Environmental parameters, such as photosynthetically active radiation (PAR), ambient $\mathrm{CO}_{2}$ concentration $\left(C_{\mathrm{a}}\right)$, air temperature $\left(T_{\mathrm{AIR}}\right)$, leaf temperature $\left(T_{\mathrm{LEAF}}\right)$, vapor pressure deficiency (VPD), and relative humidity (RH), were simultaneously obtained. Diurnal mean values of $P_{\mathrm{N}}, E$, $g_{\mathrm{s}}$, and $C_{\mathrm{i}}$ were obtained by averaging the hourly values over the period from 08:00 to 20:00.

The $P_{\mathrm{N}}$-PAR response curves of the leaves were determined by gas exchange parameters using the LI-6400 portable photosynthesis system with a red-blue LED light source $(6400-02 \mathrm{~B}) . P_{\mathrm{N}}$ was obtained from the selected leaf after $20 \mathrm{~min}$ of illumination at a photosynthetic photon flux density (PPFD) of $2000 \mu \mathrm{mol} /\left(\mathrm{m}^{2} \cdot \mathrm{s}\right) . P_{\mathrm{N}}-\mathrm{PAR}$ response curves were obtained at 14 levels of PPFD (i.e., 2000, 1800, 1500, 1200, 1000, 800, 600, 400, 200, 150, 100, 50, 20, $0 \mu \mathrm{mol} /\left(\mathrm{m}^{2} \cdot \mathrm{s}\right)$ ) under natural conditions from 09:30 to 11:30. $P_{\mathrm{N}}$-PAR response curves were fitted by the highly popular nonrectangular hyperbola (NRH) equation (Marshall and Biscoe, 1980; Thornley, 1998; Prieto et al., 2010; Calama et al., 2013), which is expressed as follows:

$$
P_{\mathrm{N}}(I)=\frac{\alpha I+P_{\text {Nmaxcal }}-\sqrt{\left(\alpha I+P_{\text {Nmaxcal }}\right)^{2}-4 \theta \alpha I P_{\text {Nmaxcal }}}}{2 \theta}-R_{\mathrm{D}},
$$

where $\alpha$ is the initial slope of the photosynthetic light-response (PLR) curves (i.e., apparent quantum efficiency, AQE); $I$ is the PPED $\left(\mu \mathrm{mol} /\left(\mathrm{m}^{2} \cdot \mathrm{s}\right)\right) ; \theta$ is the convexity; $P_{\text {Nmaxcal }}$ is the calculated maximum net photosynthetic rate $\left(\mu \mathrm{mol} \mathrm{CO}_{2} /\left(\mathrm{m}^{2} \cdot \mathrm{s}\right)\right)$; and $R_{\mathrm{D}}$ is the dark respiration inferred from response curves $\left(\mu \mathrm{mol} /\left(\mathrm{m}^{2} \cdot \mathrm{s}\right)\right)$. Parameters $\alpha, \theta, P_{\text {Nmaxcal }}$, and $R_{\mathrm{D}}$ were estimated using the nonlinear regression module in the SPSS statistical package (Version 16.0 for Windows, SPSS, Chicago, IL, USA).

After photosynthetic parameters were acquired, the following indices for the photosynthetic capacity of plants were obtained, i.e., water-use efficiency (WUE), stomatal limitation value $\left(L_{\mathrm{s}}\right)$, light compensation point (LCP), light saturation point $\left(\mathrm{LSP}_{\mathrm{obs}}\right)$, and variation ratio (VR). WUE was calculated as follows (Nijs et al., 1997):

$$
\mathrm{WUE}=P_{\mathrm{N}} / E .
$$

$L_{\mathrm{S}}$ is expressed as follows (Berry and Downton, 1982):

$$
L_{\mathrm{s}}=1-C_{\mathrm{i}} / C_{\mathrm{a}} \text {. }
$$

LCP, which occurred in the PPFD range of $0-200 \mu \mathrm{mol} /\left(\mathrm{m}^{2} \cdot \mathrm{s}\right)$, was estimated from the linear section of the $P_{\mathrm{N}}$-PAR response curves (Singsaas et al., 2001). The linear section was fitted with a linear function, and LCP was the intercept between the linear function and $x$-axis of PPFD. The observed maximum net photosynthetic rate, which was designated as $P_{\text {Nmaxobs, }}$, was observed at 14 levels of PPFD. The point of PPFD that corresponded with $P_{\text {Nmaxobs }}$ was $\mathrm{LSP}_{\text {obs. }}$ VR was the ratio between the deviations in two regions to the values in grazing plot.

\subsection{Statistical analysis}

We used SPSS (Version 19.0, SPSS Inc., Chicago, IL, USA) and Sigmaplot (Version 12.5, Systat Software Inc., San Jose, CA, USA) statistical packages to analyze measurements. The effects of fencing after years on the photosynthetic capacity of the selected species were analyzed using one-way ANOVA $(P<0.05)$. Differences in photosynthetic parameters between grazing and fencing plots were compared using least significant difference (LSD) multiple range tests at the 0.05 probability level.

\section{Results}

\subsection{Diurnal variations in environmental parameters}

PAR ranged from 62.03 to $2130.65 \mu \mathrm{mol} /\left(\mathrm{m}^{2} \cdot \mathrm{s}\right)$ during the measurement period. The highest daily values for the measurement in three days occurred at 13:00 (Fig. 2a1) and 14:00 (Figs. 2b1 and $\mathrm{c1}$ ). The variation trend in $C_{\mathrm{a}}$ during the observation period was expressed as a "W" shape (Figs. 
2a1, b1, and $\mathrm{c} 1$ ). The maximum $C_{\mathrm{a}}$ value was observed at 08:00, then decreased and reached a lower value at 11:00, then increased and reached a higher value at 14:00, and then decreased to the lowest value at approximately 18:00, from then increased again until 20:00. The diurnal patterns of $T_{\mathrm{AIR}}$ and $T_{\mathrm{LEAF}}$ were similar, and their maximum values appeared at approximately 13:00 (Figs. 2a2, b2, and c2). The maximum and minimum values of RH were observed at 08:00 and at approximately 14:00, respectively. The diurnal pattern of VPD was opposite to that of RH (Figs. 2a3, b3, and c3).

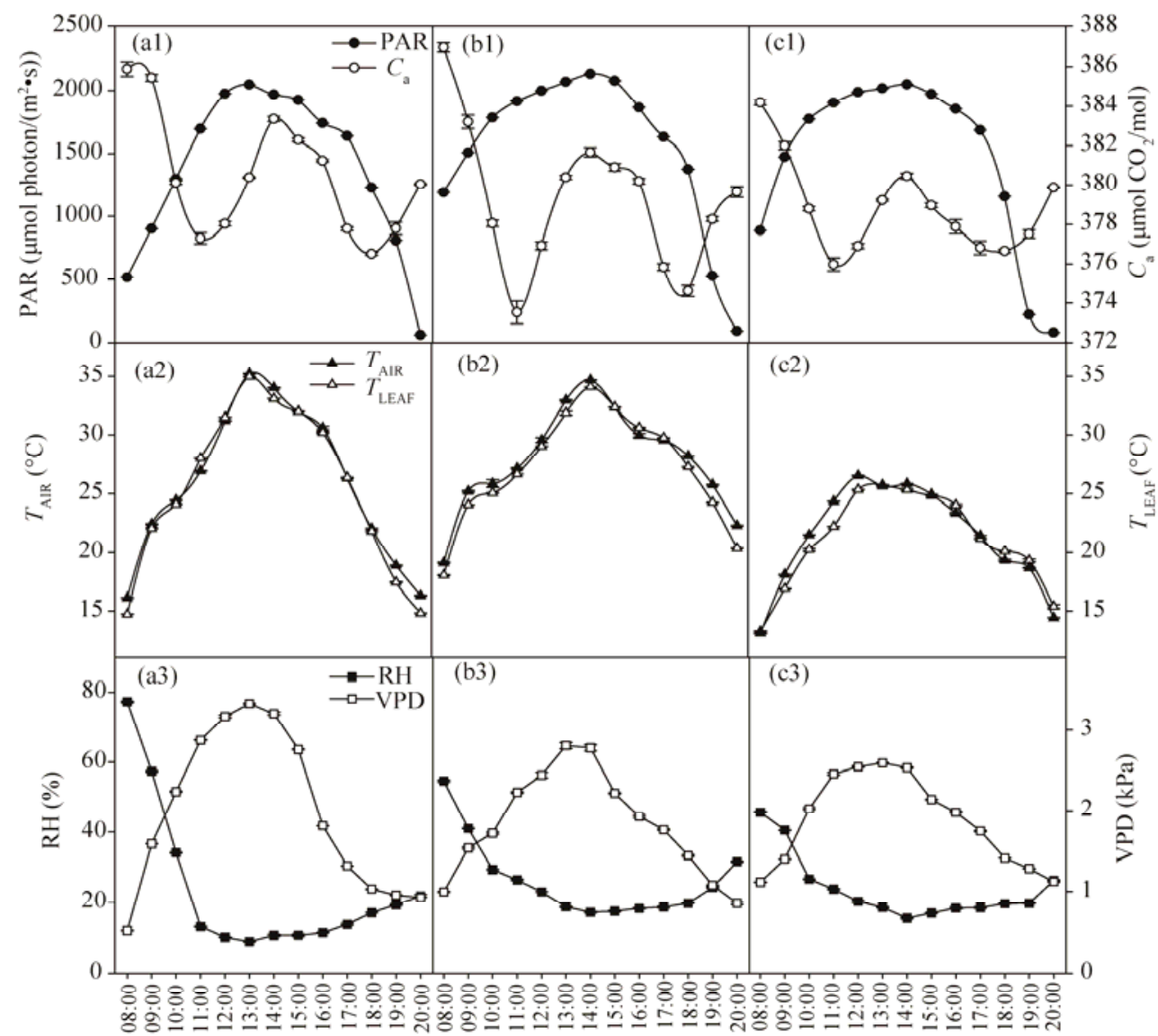

Time (LST)

Fig. 2 Diurnal variations of photosynthetically active radiation (PAR) (a1, b1, and c1), ambient $\mathrm{CO}_{2}$ concentration $\left(C_{\mathrm{a}}\right)(\mathrm{a} 1, \mathrm{~b} 1$, and $\mathrm{c} 1)$, air temperature $\left(T_{\mathrm{AIR}}\right)(\mathrm{a} 2, \mathrm{~b} 2$, and $\mathrm{c} 2)$, leaf temperature $\left(T_{\mathrm{LEAF}}\right)(\mathrm{a} 2, \mathrm{~b} 2$, and c2), relative humidity (RH) (a3, b3, and c3), and vapor pressure deficient (VPD) (a3, b3, and c3). a, b, and c are the dates of 25 June, 23 July, and 26 August in 2016, respectively. Bars mean standard errors; $n=6$.

\subsection{Diurnal variations in photosynthetic parameters}

According to plant growth period, we chose the early (25 June), medium (23 July) and late (26 August) stages of plant growth for the measurement of the photosynthetic parameters. Diurnal variations in $P_{\mathrm{N}}, E$, and $g_{\mathrm{s}}$ exhibited double-peaked curves under grazing and fencing conditions (Figs. 3 and 4). There existed lower values between two peaks. This phenomenon, which is called midday photosynthetic depression, occurred from 12:00 to 16:00 (Figs. 3a1, b1, and c1 and Figs. $4 \mathrm{a} 1, \mathrm{~b} 1$, and $\mathrm{c} 1)$.

3.2.1 Diurnal patterns of photosynthetic parameters for $E$. nutans

Under fencing conditions, the maximum values of $P_{\mathrm{N}}$ on 25 June, $23 \mathrm{July}$, and 26 August were $13.20,16.40$, and $14.92 \mu \mathrm{mol} \mathrm{CO}_{2} /\left(\mathrm{m}^{2} \cdot \mathrm{s}\right)$, respectively. The maximum values in grazing plot 


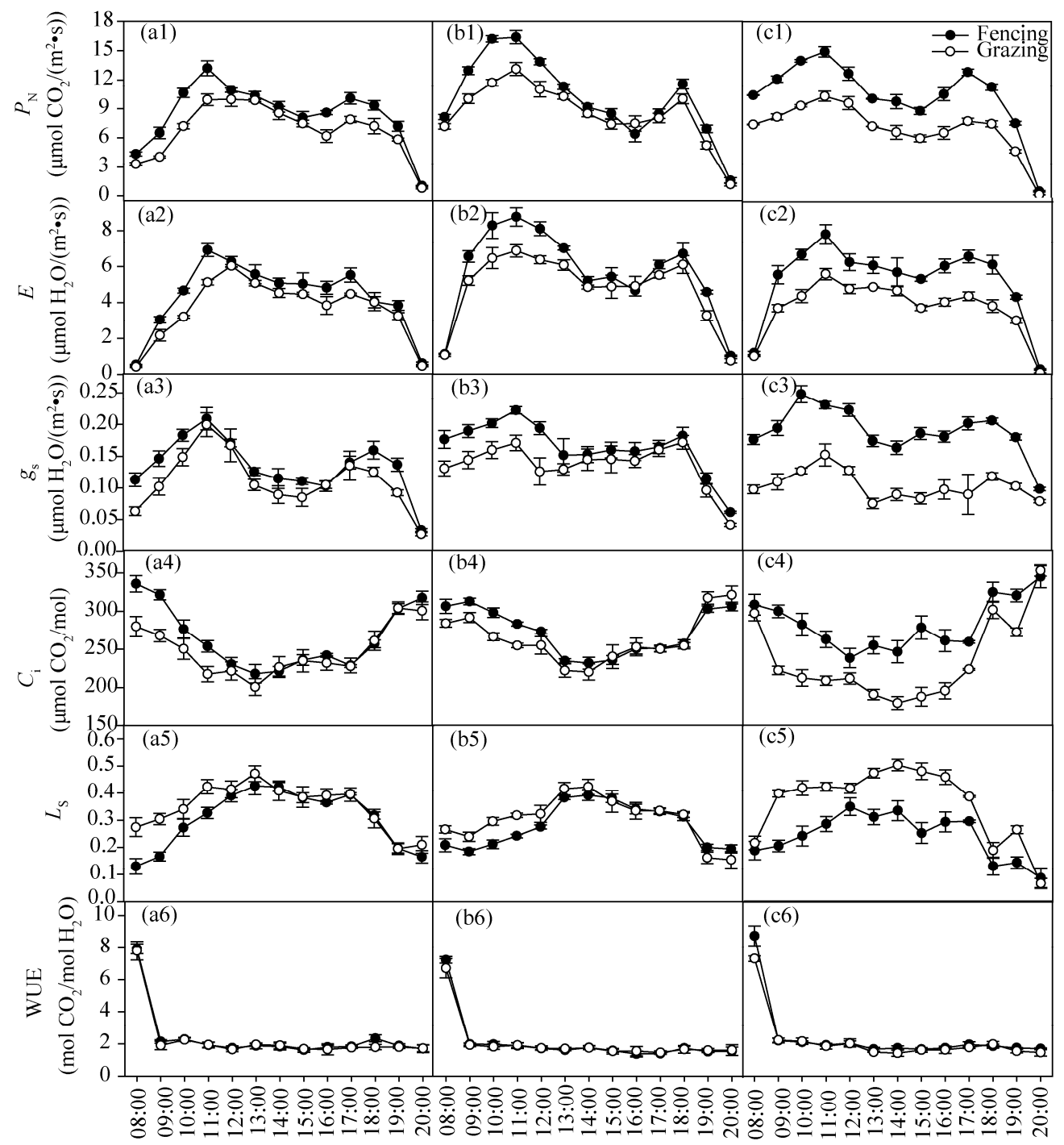

Time (LST)

Fig. 3 Diurnal patterns of net photosynthetic rate $\left(P_{\mathrm{N}}\right)(\mathrm{a} 1, \mathrm{~b} 1$, and $\mathrm{c} 1)$, transpiration rate $(E)(\mathrm{a} 2$, b2, and $\mathrm{c} 2)$, stomatal conductance $\left(g_{\mathrm{s}}\right)(\mathrm{a} 3, \mathrm{~b} 3$, and $\mathrm{c} 3)$, intercellular $\mathrm{CO}_{2}$ concentration $\left(C_{\mathrm{i}}\right)(\mathrm{a} 4$, b4, and $\mathrm{c} 4)$, stomatal limitation value $\left(L_{\mathrm{s}}\right)(\mathrm{a} 5, \mathrm{~b} 5$, and $\mathrm{c} 5)$, and water-use efficiency (WUE) (a6, b6, and c6) for E. nutans grown in fencing and grazing plots. a, b and c are the dates of 25 June, 23 July, and 26 August in 2016, respectively. Bars mean standard errors; $n=6$.

were lower than those in fencing plot. The first peak occurred at 11:00 under fencing and grazing conditions. The second peak occurred at approximately 17:30 for both regimes (Figs. 3a1, b1, and c1).

The diurnal patterns of $E$ and $g_{\mathrm{s}}$ were similar to that of $P_{\mathrm{N}}$ and formed an "M" shape. $E$ and $g_{\mathrm{s}}$ increased with time and the first peak occurred at 11:00 and then decreased and reached the lower values at approximately 15:00, after that, $E$ and $g_{\text {s }}$ increased again to the second peak at approximately 17:30, and then, declined until 20:00 (Figs. 3a2, b2, and c2). However, the maximum $g_{\mathrm{s}}$ values occurred $1 \mathrm{~h}$ earlier in fencing plot than in grazing plot on 26 August (Figs. $3 \mathrm{a} 3, \mathrm{~b} 3$, and $\mathrm{c} 3$ ).

The diurnal pattern of $C_{\mathrm{i}}$ differed from those of $P_{\mathrm{N}}, E$, and $g_{\mathrm{s}}$. In our study area, $C_{\mathrm{i}}$ firstly reached the maximum values at 08:00 except on 26 August, then decreased and reached the daily minimum values at approximately 12:00, and remained at the low levels for approximately $5 \mathrm{~h}$ until 17:00 (Figs. 3a4, b4, and c4). The trends of the diurnal variations in $L_{\mathrm{s}}$ were opposed to 
those of $C_{\mathrm{i}}$ (Figs. 3a5, b5, and c5).

Diurnal variations in WUE followed an "L" shape under fencing and grazing conditions. The maximum WUE appeared at 08:00, then sharply declined to a lower value approximately at 09:00, and remained the low level for approximately $11 \mathrm{~h}$ (Figs. 3a6, b6, and c6).

Through statistical analysis, we found that there were significantly different photosynthetic parameters in fencing and grazing plots (Table 3 ). The daily mean values of photosynthetic parameters $\left(P_{\mathrm{N}}, E, g_{\mathrm{s}}\right.$, and $\left.C_{\mathrm{i}}\right)$ in fencing plot were significantly higher than those in grazing plot. On the contrary, the daily mean values of $L_{\mathrm{s}}$ in fencing plot were significantly lower than those in grazing plot. There were no significantly differences of WUE on 23 July between fencing and grazing plots. In addition, the daily mean values of parameters $\left(E, g_{\mathrm{s}}, C_{\mathrm{i}}\right.$, and $\left.L_{\mathrm{s}}\right)$ significantly differed on different observation dates in fencing plot, while daily mean values of WUE significantly differed on different observation dates in grazing plot (Table 4). Under fencing condition, the percentages of variation of the $P_{\mathrm{N}}, E, g_{\mathrm{s}}, C_{\mathrm{i}}, L_{\mathrm{s}}$, and WUE for the E. nutans were $30.3 \%, 26.1 \%, 41.3 \%, 9.7 \%,-17.8 \%$, and $4.5 \%$, respectively (Table 3 ).

Table 3 Analysis of differences of $P_{\mathrm{N}}, E, g_{\mathrm{s}}, C_{\mathrm{i}}, L_{\mathrm{s}}$, and WUE for $E$. nutans and $P$. anserina in fencing plots

\begin{tabular}{|c|c|c|c|c|c|c|c|c|}
\hline Species & Regime & Date & $P_{\mathrm{N}} /(\mathrm{VR})$ & $E /(\mathrm{VR})$ & $g_{\mathrm{s}} /(\mathrm{VR})$ & $C_{\mathrm{i}} /(\mathrm{VR})$ & $L_{\mathrm{s}} /(\mathrm{VR})$ & WUE/(VR) \\
\hline \multirow{4}{*}{ E. nutans } & \multirow{4}{*}{ Fencing } & 25 June & $* * /(24.0 \%)$ & $* * /(18.8 \%)$ & $* * /(20.9 \%)$ & $* * /(6.7 \%)$ & $* * /(-12.5 \%)$ & $* /(3.6 \%)$ \\
\hline & & 23 July & $* * /(18.3 \%)$ & $* * /(17.9 \%)$ & $* * /(20.7 \%)$ & $* * /(3.3 \%)$ & $* * /(-7.5 \%)$ & $* /(1.1 \%)$ \\
\hline & & 26 August & $* * /(48.5 \%)$ & $* * /(41.6 \%)$ & $* * /(82.3 \%)$ & $* * /(19.0 \%)$ & $* * /(-33.4 \%)$ & $* * /(9.0 \%)$ \\
\hline & & Total & $* * /(30.3 \%)$ & $* * /(26.1 \%)$ & $* * /(41.3 \%)$ & $* * /(9.7 \%)$ & $* * /(-17.8 \%)$ & $* /(4.5 \%)$ \\
\hline \multirow{4}{*}{ P. anserina } & \multirow{4}{*}{ Fencing } & 25 June & $* * /(19.9 \%)$ & $* * /(17.0 \%)$ & $* * /(10.6 \%)$ & $* * /(6.7 \%)$ & $* * /(-17.1 \%)$ & $* /(4.0 \%)$ \\
\hline & & 23 July & $* * /(14.7 \%)$ & $* * /(18.3 \%)$ & $* * /(7.8 \%)$ & $* * /(5.8 \%)$ & $* * /(-18.2 \%)$ & $* /(0.3 \%)$ \\
\hline & & 26 August & $* * /(11.6 \%)$ & $\mathrm{NS} /(4.0 \%)$ & $\mathrm{NS} /(8.9 \%)$ & $\mathrm{NS} /(0.7 \%)$ & $\mathrm{NS} /(-2.0 \%)$ & $\mathrm{NS} /(5.2 \%)$ \\
\hline & & Total & $* * /(15.4 \%)$ & $* /(13.1 \%)$ & $* /(9.1 \%)$ & $* /(4.4 \%)$ & $* /(-12.5 \%)$ & $\mathrm{NS} /(3.1 \%)$ \\
\hline
\end{tabular}

Note: $P_{\mathrm{N}}$, net photosynthetic rate; $E$, transpiration rate; $g_{\mathrm{s}}$, stomatal conductance; $C_{\mathrm{i}}$, intercellular $\mathrm{CO}_{2}$ concentration; $L_{\mathrm{s}}$, stomatal limitation value; WUE, water-use efficiency. * and ** indicate the significances at $P<0.05$ and $P<0.01$ levels, respectively; NS, not significant. VR, variation ratio.

\subsubsection{Diurnal patterns of photosynthetic parameters for $P$. anserina}

Under fencing conditions, the maximum values of $P_{\mathrm{N}}$ on 25 June, $23 \mathrm{July}$, and 26 August were $19.84,22.91$ and $18.99 \mu \mathrm{mol} \mathrm{CO} \mathrm{CO}_{2} /\left(\mathrm{m}^{2} \cdot \mathrm{s}\right)$, respectively (Fig. 4). The maximum values in fencing plot were significantly higher than those in grazing plot. The peak values occurred at the same time as E. nutans (Figs. 4a1, b1, and c1).

The diurnal patterns of $E$ and $g_{\mathrm{s}}$ were similar to that of $P_{\mathrm{N}}$. However, the second peak values of $E$ and $g_{\mathrm{s}}$ occurred $1 \mathrm{~h}$ later on 23 July and 26 August than those of $P_{\mathrm{N}}$ in fencing and grazing plots (Figs. 4b2, c2 and Figs. 4b3, c3).

Diurnal pattern of $C_{\mathrm{i}}$ differed from that of $P_{\mathrm{N}}$. The maximum $C_{\mathrm{i}}$ values occurred at 08:00, decreased to the daily minimum values at approximately 15:00, and remained at low levels for approximately $4 \mathrm{~h}$ until 19:00 (Figs. 4a4, b4, and c4). The trends of the diurnal variations in $L_{\mathrm{s}}$ were opposed to those of $C_{\mathrm{i}}$ (Figs. $4 \mathrm{a} 5$, b5, and c5).

The diurnal pattern of WUE followed an "L" shape under two regimes. The maximum values of WUE appeared at 08:00, declined sharply to lower value at approximately 09:00 except on 25 June, and remained low for approximately $10 \mathrm{~h}$ (Figs. 4a6, b6, and c6).

Through statistical analysis, there were significantly different photosynthetic parameters on 25 June and 23 July in fencing and grazing plots. There were no significantly differences of these parameters $\left(E, g_{\mathrm{s}}, C_{\mathrm{i}}, L_{\mathrm{s}}\right.$, and WUE) on 26 August under two regimes (Table 3$)$. The daily mean values of photosynthetic parameters $\left(P_{\mathrm{N}}, E, g_{\mathrm{s}}\right.$, and $\left.C_{\mathrm{i}}\right)$ were significantly higher in fencing plot than in grazing plot on 25 June and 23 July. On the contrary, the daily mean values of $L_{\mathrm{s}}$ were significantly lower in fencing plot than in grazing plot on 25 June and 23 July. Furthermore, the daily mean values of $g_{\mathrm{s}}, C_{\mathrm{i}}$, and $L_{\mathrm{s}}$ significantly differed on different observation dates both in grazing and fencing plots. Daily mean values of $P_{\mathrm{N}}$ and $E$ significantly differed on different observation dates in fencing plot (Table 4). Compared with grazing plot, the percentages of variation of the $P_{\mathrm{N}}, E, g_{\mathrm{s}}, C_{\mathrm{i}}, L_{\mathrm{s}}$, and WUE in fencing plot for the $P$. anserina were $15.4 \%, 13.1 \%$, $9.1 \%, 4.4 \%,-12.5 \%$, and $3.1 \%$, respectively (Table 3 ). 
Table 4 Daily photosynthetic parameters $\left(P_{\mathrm{N}}, E, g_{\mathrm{s}}, C_{\mathrm{i}}, L_{\mathrm{s}}\right.$, and WUE) in E. nutans and $P$. anserina on different measuring dates in fencing and grazing plots

\begin{tabular}{|c|c|c|c|c|c|}
\hline Species & Parameter & Treatment & 25 June & 23 July & 26 August \\
\hline \multirow{12}{*}{ E. nutans } & \multirow{2}{*}{$P_{\mathrm{N}}\left(\mu \mathrm{mol} \mathrm{CO} \mathrm{CO}_{2} /\left(\mathrm{m}^{2} \cdot \mathrm{s}\right)\right)$} & Grazing & $6.80 \pm 0.36^{\mathrm{bB}}$ & $8.56 \pm 0.40^{\mathrm{aB}}$ & $7.01 \pm 0.31^{\mathrm{bB}}$ \\
\hline & & Fencing & $8.43 \pm 0.32^{\mathrm{bA}}$ & $10.12 \pm 0.35^{\mathrm{aA}}$ & $10.40 \pm 0.33^{\mathrm{aA}}$ \\
\hline & \multirow{2}{*}{$\left.E\left(\mathrm{mmol} \mathrm{H}{ }_{2} \mathrm{O}\right) /\left(\mathrm{m}^{2} \cdot \mathrm{s}\right)\right)$} & Grazing & $3.63 \pm 0.05^{\mathrm{bB}}$ & $4.80 \pm 0.08^{\mathrm{aB}}$ & $3.68 \pm 0.08^{\mathrm{bB}}$ \\
\hline & & Fencing & $4.31 \pm 0.21^{\mathrm{cA}}$ & $5.67 \pm 0.22^{\mathrm{aA}}$ & $5.22 \pm 0.24^{\mathrm{bA}}$ \\
\hline & \multirow{2}{*}{$g_{\mathrm{s}}\left(\mathrm{mol} \mathrm{H} \mathrm{H}_{2} \mathrm{O} /\left(\mathrm{m}^{2} \cdot \mathrm{s}\right)\right)$} & Grazing & $0.111 \pm 0.007^{\mathrm{bB}}$ & $0.136 \pm 0.010^{\mathrm{aB}}$ & $0.104 \pm 0.008^{\mathrm{bB}}$ \\
\hline & & Fencing & $0.134 \pm 0.005^{\mathrm{cA}}$ & $0.164 \pm 0.011^{\mathrm{bA}}$ & $0.190 \pm 0.004^{\mathrm{aA}}$ \\
\hline & \multirow{2}{*}{$C_{\mathrm{i}}(\mu \mathrm{mol} \mathrm{CO} / 2 \mathrm{~mol})$} & Grazing & $248.20 \pm 10.5^{\mathrm{bB}}$ & $263.80 \pm 6.30^{\mathrm{aB}}$ & $241.40 \pm 7.40^{\mathrm{bB}}$ \\
\hline & & Fencing & $264.80 \pm 6.80^{\mathrm{cA}}$ & $272.50 \pm 2.40^{\mathrm{bA}}$ & $287.40 \pm 10.80^{\mathrm{aA}}$ \\
\hline & \multirow{2}{*}{$L_{\mathrm{s}}$} & Grazing & $0.348 \pm 0.028^{\mathrm{aA}}$ & $0.304 \pm 0.017^{\mathrm{bA}}$ & $0.363 \pm 0.020^{\mathrm{aA}}$ \\
\hline & & Fencing & $0.304 \pm 0.018^{\mathrm{aB}}$ & $0.281 \pm 0.006^{\mathrm{bB}}$ & $0.241 \pm 0.029^{\mathrm{cB}}$ \\
\hline & \multirow{2}{*}{ WUE $\left(\mathrm{mol} \mathrm{CO}_{2} / \mathrm{mol} \mathrm{H}_{2} \mathrm{O}\right)$} & Grazing & $2.29 \pm 0.06^{\mathrm{aB}}$ & $2.07 \pm 0.07^{\mathrm{cA}}$ & $2.19 \pm 0.08^{\mathrm{bB}}$ \\
\hline & & Fencing & $2.37 \pm 0.07^{\mathrm{aA}}$ & $2.10 \pm 0.05^{\mathrm{bA}}$ & $2.39 \pm 0.07^{\mathrm{aA}}$ \\
\hline \multirow{12}{*}{$\begin{array}{c}P . \\
\text { anserina }\end{array}$} & \multirow{2}{*}{$P_{\mathrm{N}}\left(\mu \mathrm{mol} \mathrm{CO} \mathrm{CO}_{2} /\left(\mathrm{m}^{2} \cdot \mathrm{s}\right)\right)$} & Grazing & $11.95 \pm 0.59^{\mathrm{bB}}$ & $14.52 \pm 0.59^{\mathrm{aB}}$ & $11.38 \pm 0.65^{\mathrm{bB}}$ \\
\hline & & Fencing & $14.33 \pm 0.62^{\mathrm{bA}}$ & $16.67 \pm 0.45^{\mathrm{aA}}$ & $12.70 \pm 0.67^{\mathrm{cA}}$ \\
\hline & \multirow{2}{*}{$E\left(\mathrm{mmol} \mathrm{H}_{2} \mathrm{O} /\left(\mathrm{m}^{2} \cdot \mathrm{s}\right)\right)$} & Grazing & $4.83 \pm 0.09^{\mathrm{bB}}$ & $6.11 \pm 0.13^{\mathrm{aB}}$ & $4.80 \pm 0.25^{\mathrm{bA}}$ \\
\hline & & Fencing & $5.65 \pm 0.20^{\mathrm{bA}}$ & $7.23 \pm 0.16^{\mathrm{aA}}$ & $5.00 \pm 0.26^{\mathrm{cA}}$ \\
\hline & \multirow{2}{*}{$g_{\mathrm{s}}\left(\mathrm{mol} \mathrm{H} \mathrm{H}_{2} \mathrm{O} /\left(\mathrm{m}^{2} \cdot \mathrm{s}\right)\right)$} & Grazing & $0.303 \pm 0.019^{\mathrm{bB}}$ & $0.464 \pm 0.011^{\mathrm{aB}}$ & $0.267 \pm 0.003^{\mathrm{cA}}$ \\
\hline & & Fencing & $0.335 \pm 0.029^{\mathrm{bA}}$ & $0.500 \pm 0.008^{\mathrm{aA}}$ & $0.291 \pm 0.006^{\mathrm{cA}}$ \\
\hline & \multirow{2}{*}{$C_{\mathrm{i}}(\mu \mathrm{mol} \mathrm{CO} / \mathrm{mol})$} & Grazing & $273.80 \pm 0.90^{\mathrm{cB}}$ & $287.40 \pm 1.50^{\mathrm{aB}}$ & $280.40 \pm 0.20^{\mathrm{bA}}$ \\
\hline & & Fencing & $292.20 \pm 1.10^{\mathrm{bA}}$ & $304.10 \pm 0.10^{\mathrm{aA}}$ & $282.40 \pm 0.60^{\mathrm{cA}}$ \\
\hline & \multirow{2}{*}{$L_{\mathrm{s}}$} & Grazing & $0.280 \pm 0.002^{\mathrm{aA}}$ & $0.242 \pm 0.004^{\mathrm{bA}}$ & $0.260 \pm 0.001^{\mathrm{cA}}$ \\
\hline & & Fencing & $0.232 \pm 0.003^{\mathrm{cB}}$ & $0.198 \pm 0.001^{\mathrm{bB}}$ & $0.255 \pm 0.002^{\mathrm{aA}}$ \\
\hline & \multirow{2}{*}{ WUE $\left(\mathrm{mol} \mathrm{CO} \mathrm{CO}_{2} / \mathrm{mol} \mathrm{H}_{2} \mathrm{O}\right)$} & Grazing & $3.06 \pm 0.14^{\mathrm{bB}}$ & $3.03 \pm 0.14^{\mathrm{bA}}$ & $3.22 \pm 0.45^{\mathrm{aA}}$ \\
\hline & & Fencing & $3.19 \pm 0.14^{\mathrm{abA}}$ & $3.04 \pm 0.09^{\mathrm{bA}}$ & $3.39 \pm 0.29^{\mathrm{aA}}$ \\
\hline
\end{tabular}

Note: $P_{\mathrm{N}}$, net photosynthetic rate; $E$, transpiration rate; $g_{\mathrm{s}}$, stomatal conductance; $C_{\mathrm{i}}$, intercellular $\mathrm{CO}_{2}$ concentration; $L_{\mathrm{s}}$, stomatal limitation value; WUE, water-use efficiency. Different lowercase letters mean significant differences in the same treatment at $P<0.05$ level under different observation dates. Different uppercase letters indicate significant differences on the same measuring date at $P<0.05$ level under two treatments. Mean \pm SE, $n=6$.

\section{3 $\quad P_{\mathrm{N}}$-PAR curves}

The $P_{\mathrm{N}}$-PAR response curves were well fitted by NRH $\left(R^{2}>0.997\right.$; Fig. 5; Table 5), suggesting that these two species exhibited distinct light saturation phenomenon. Differences of $P_{\text {Nmaxobs, }}$, $P_{\text {Nmaxcal }}$, AQE (i.e., $\alpha$ in Equation 1 ), $R_{\mathrm{D}}, \mathrm{LCP}$, and $\mathrm{LSP}_{\text {obs }}$ in two included species between fencing and grazing plots were statistically significant (Table 6).

The values of $P_{\text {Nmaxobs}}, P_{\text {Nmaxcal }}, \mathrm{AQE}, R_{\mathrm{D}}, \mathrm{LCP}$, and $\mathrm{LSP}_{\text {obs }}$ from $E$. nutans and $P$. anserina on different measuring dates in fencing plot were significantly higher than their corresponding values in grazing plot (Table 5). Significant differences were found in parameters $\left(P_{\text {Nmaxobs }}, P_{\text {Nmaxcal }}, R_{\mathrm{D}}\right.$, and $\mathrm{LSP}_{\mathrm{obs}}$ ) for both species among three measurement dates within a given regime. Under grazing conditions, the AQE of E. nutans was not significantly different between 23 July and 26 August, and $P$. anserina exhibited the same results between 25 June and 26 August. The LCP values of $E$. nutans between 25 June and 26 August were not significantly different under grazing conditions but were significantly different under fencing conditions. LCP values of $E$. nutans between 23 July and 26 August were not significantly different under fencing conditions but were significantly different under grazing conditions. The LCP values of $P$. anserina were significantly different between two regimes, and across different observation dates. The maximum parameter values $\left(P_{\text {Nmaxobs}}, P_{\text {Nmaxcal }}, \mathrm{AQE}, R_{\mathrm{D}}, \mathrm{LCP}\right.$, and $\left.\mathrm{LSP}_{\text {obs }}\right)$ of $E$. nutans occurred on $23 \mathrm{July}$ 


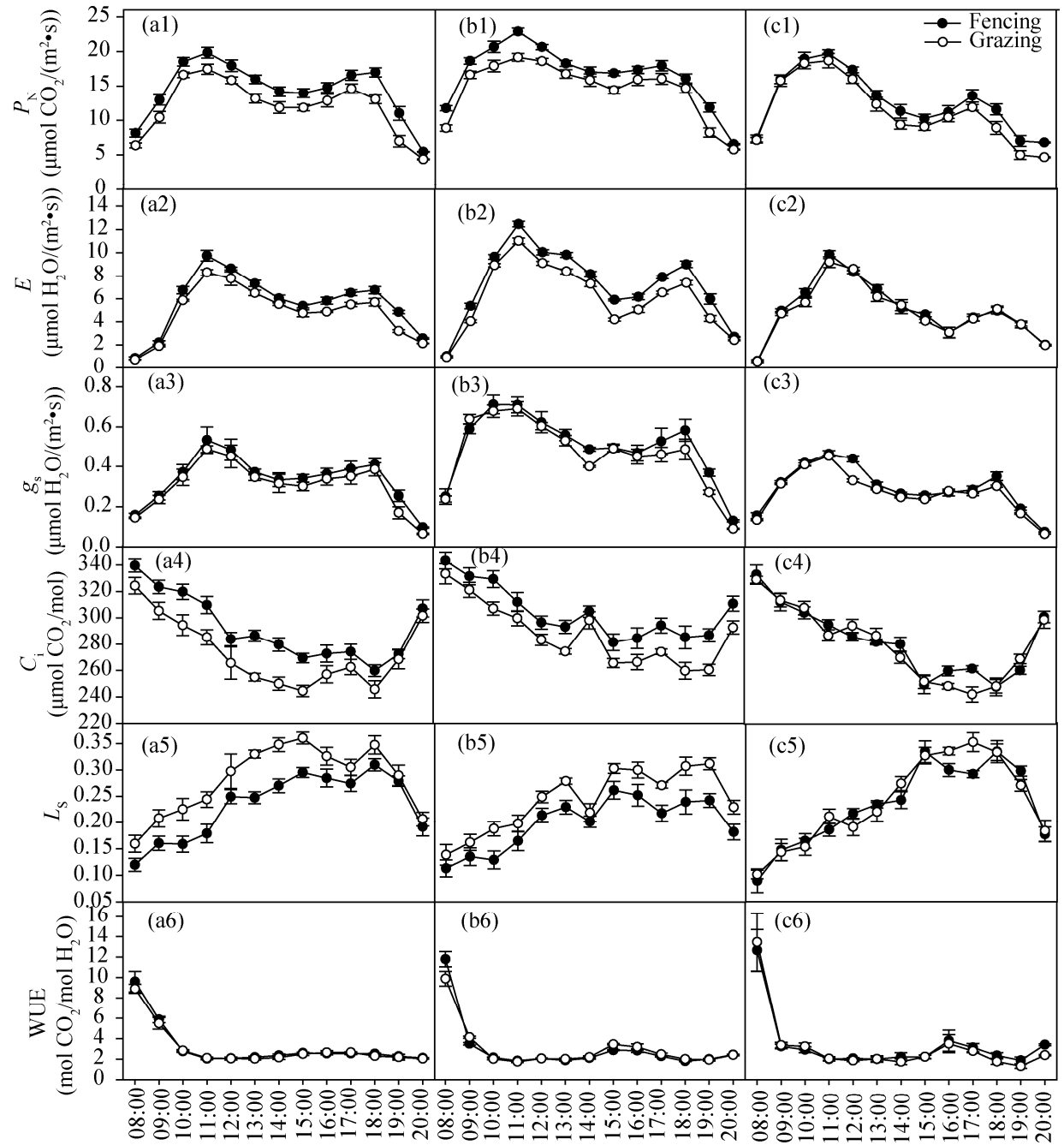

Time (LST)

Fig. 4 Diurnal patterns of net photosynthetic rate $\left(P_{\mathrm{N}}\right)(\mathrm{a} 1, \mathrm{~b} 1$, and $\mathrm{c} 1)$, transpiration rate $(E)(\mathrm{a} 2, \mathrm{~b} 2$, and $\mathrm{c} 2)$, stomatal conductance $\left(g_{\mathrm{s}}\right)(\mathrm{a} 3, \mathrm{~b} 3$, and $\mathrm{c} 3)$, intercellular $\mathrm{CO}_{2}$ concentration $\left(C_{\mathrm{i}}\right)(\mathrm{a} 4$, b4, and $\mathrm{c} 4)$, stomatal limitation value $\left(L_{\mathrm{s}}\right)(\mathrm{a} 5, \mathrm{~b} 5$, and $\mathrm{c} 5)$, and water-use efficiency (WUE) (a6, b6, and $\mathrm{c} 6$ ) for P. anserina grown in fencing and grazing plots. a, b and c are the dates of 25 June, 23 July, and 26 August in 2016, respectively. Bars mean standard errors; $n=6$.

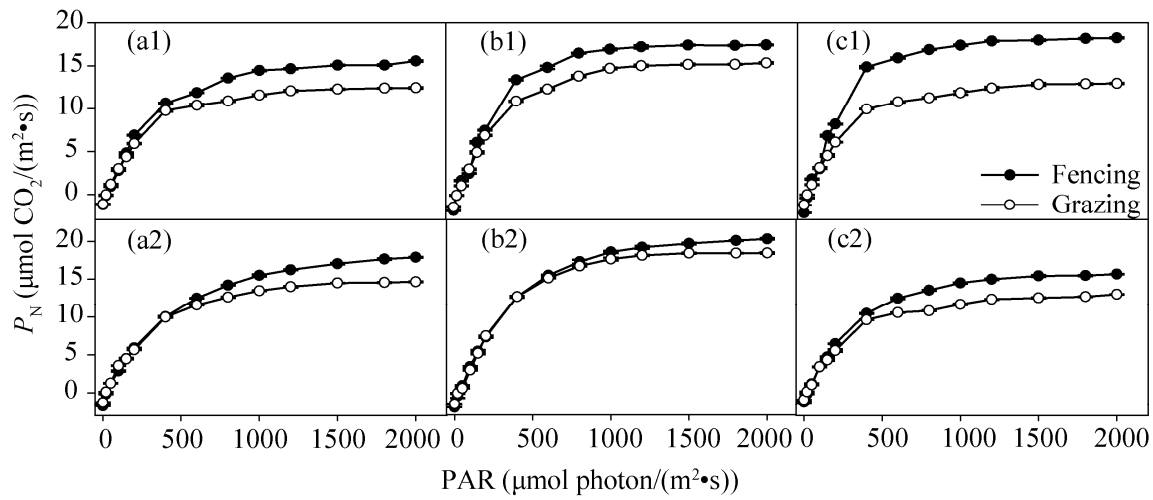

Fig. $5 P_{\mathrm{N}}$-PAR (net photosynthetic rate-photosynthetically active radiation) response curves for $E$. nutans (a1, $\mathrm{b} 1$, and $\mathrm{c} 1)$ and P. anserina (a2, $\mathrm{b} 2$, and $\mathrm{c} 2$ ) under different measuring dates in fencing and grazing plots. $\mathrm{a}, \mathrm{b}$, and $\mathrm{c}$ are the dates of 25 June, 23 July, and 26 August in 2016, respectively. Bars mean standard errors; $n=6$. 
in grazing plot, and on 26 August in fencing plot. Whereas the minimum parameter values of $E$. nutans occurred on 25 June in both grazing and fencing plots. For each plot of $P$. anserina, the maximum and minimum parameter values ( $P_{\text {Nmaxobs, }} P_{\text {Nmaxcal }}, \mathrm{AQE}, R_{\mathrm{D}}, \mathrm{LCP}$, and $\left.\mathrm{LSP}_{\text {obs }}\right)$ occurred on 23 July and 25 June, respectively. $P_{\text {Nmaxobs }}$ and $P_{\text {Nmaxcal }}$ exhibited similar variation trends across different observation dates and under both regimes (Table 5). However, $P_{\text {Nmaxcal }}$ was higher than $P_{\text {Nmaxobs }}$ for both species under both regimes.

Table 5 Values of parameters $\left(P_{\text {Nmaxobs}}, P_{\text {Nmaxcal }}, \mathrm{AQE}, R_{\mathrm{D}}\right.$, LCP, and $\left.\mathrm{LSP}_{\mathrm{obs}}\right)$ for $E$. nutans and $P$. anserina on different measuring dates in fencing and grazing plots

\begin{tabular}{|c|c|c|c|c|c|}
\hline Species & Parameter & Treatment & 25 June & 23 July & 26 August \\
\hline \multirow{14}{*}{ E. nutans } & \multirow{2}{*}{$P_{\text {Nmaxobs }}\left(\mu \mathrm{mol} \mathrm{CO} 2 /\left(\mathrm{m}^{2} \cdot \mathrm{s}\right)\right)$} & Grazing & $12.46 \pm 0.08^{\mathrm{cB}}$ & $15.38 \pm 0.08^{\mathrm{aB}}$ & $12.96 \pm 0.08^{\mathrm{bB}}$ \\
\hline & & Fencing & $15.58 \pm 0.10^{\mathrm{cA}}$ & $17.46 \pm 0.05^{\mathrm{bA}}$ & $18.26 \pm 0.06^{\mathrm{aA}}$ \\
\hline & \multirow{2}{*}{$P_{\text {Nmaxcal }}\left(\mu \mathrm{mol} \mathrm{CO} /\left(\mathrm{m}^{2} \cdot \mathrm{s}\right)\right)$} & Grazing & $14.11 \pm 0.09^{\mathrm{cB}}$ & $17.84 \pm 0.08^{\mathrm{aB}}$ & $14.86 \pm 0.21^{\mathrm{bB}}$ \\
\hline & & Fencing & $17.99 \pm 0.12^{\mathrm{cA}}$ & $19.69 \pm 0.07^{\mathrm{bA}}$ & $20.45 \pm 0.14^{\mathrm{aA}}$ \\
\hline & \multirow{2}{*}{$\begin{array}{c}\mathrm{AQE}\left(\mu \mathrm{mol} \mathrm{CO} \mathrm{CO}_{2} / \mu \mathrm{mol}\right. \\
\text { photon })\end{array}$} & Grazing & $0.044 \pm 0.001^{\mathrm{bB}}$ & $0.049 \pm 0.001^{\mathrm{aB}}$ & $0.047 \pm 0.001^{\mathrm{aB}}$ \\
\hline & & Fencing & $0.049 \pm 0.001^{\mathrm{cA}}$ & $0.051 \pm 0.001^{\mathrm{bA}}$ & $0.059 \pm 0.001^{\mathrm{aA}}$ \\
\hline & \multirow{2}{*}{$\mathrm{R}_{\mathrm{D}}\left(\mu \mathrm{mol} \mathrm{CO} \mathrm{CO}_{2} /\left(\mathrm{m}^{2} \cdot \mathrm{s}\right)\right)$} & Grazing & $1.052 \pm 0.042^{\mathrm{cB}}$ & $1.323 \pm 0.017^{\mathrm{aB}}$ & $1.141 \pm 0.013^{\mathrm{bB}}$ \\
\hline & & Fencing & $1.284 \pm 0.018^{\mathrm{cA}}$ & $1.490 \pm 0.042^{\mathrm{bA}}$ & $1.792 \pm 0.036^{\mathrm{aA}}$ \\
\hline & \multirow{2}{*}{$\mathrm{LCP}\left(\mu \mathrm{mol}\right.$ photon $\left./\left(\mathrm{m}^{2} \cdot \mathrm{s}\right)\right)$} & Grazing & $23.72 \pm 0.90^{\mathrm{bB}}$ & $28.47 \pm 0.54^{\mathrm{aB}}$ & $24.34 \pm 0.77^{\mathrm{bB}}$ \\
\hline & & Fencing & $27.91 \pm 0.48^{\mathrm{bA}}$ & $31.53 \pm 0.92^{\mathrm{aA}}$ & $32.08 \pm 0.29^{\mathrm{aA}}$ \\
\hline & \multirow{2}{*}{$\begin{array}{l}\operatorname{LSP}_{\text {obs }}(\mu \mathrm{mol} \\
\left.\text { photon } /\left(\mathrm{m}^{2} \cdot \mathrm{s}\right)\right)\end{array}$} & Grazing & $1109.40 \pm 7.10^{\mathrm{cB}}$ & $1193.80 \pm 3.30^{\mathrm{aB}}$ & $1141.80 \pm 6.40^{\mathrm{bB}}$ \\
\hline & & Fencing & $1199.40 \pm 6.30^{\mathrm{cA}}$ & $1256.60 \pm 7.10^{\mathrm{bA}}$ & $1291.20 \pm 8.70^{\mathrm{aA}}$ \\
\hline & \multirow{2}{*}{$R^{2}$} & Grazing & 0.997 & 0.999 & 0.998 \\
\hline & & Fencing & 0.998 & 0.997 & 0.997 \\
\hline \multirow{14}{*}{$\begin{array}{c}P . \\
\text { anserina }\end{array}$} & \multirow{2}{*}{$P_{\text {Nmaxobs }}\left(\mu \mathrm{mol} \mathrm{CO} \mathrm{CO}_{2} /\left(\mathrm{m}^{2} \cdot \mathrm{s}\right)\right)$} & Grazing & $14.65 \pm 0.03^{\mathrm{bB}}$ & $18.39 \pm 0.06^{\mathrm{aB}}$ & $12.99 \pm 0.03^{\mathrm{cb}}$ \\
\hline & & Fencing & $17.90 \pm 0.04^{\mathrm{bA}}$ & $20.25 \pm 0.11^{\mathrm{aA}}$ & $15.67 \pm 0.04^{\mathrm{cA}}$ \\
\hline & \multirow{2}{*}{$P_{\text {Nmaxcal }}\left(\mu \mathrm{mol} \mathrm{CO} \mathrm{CO}_{2} /\left(\mathrm{m}^{2} \cdot \mathrm{s}\right)\right)$} & Grazing & $17.24 \pm 0.05^{\mathrm{bB}}$ & $21.07 \pm 0.09^{\mathrm{aB}}$ & $14.66 \pm 0.06^{\mathrm{cB}}$ \\
\hline & & Fencing & $22.86 \pm 0.15^{\mathrm{bA}}$ & $24.07 \pm 0.10^{\mathrm{aA}}$ & $18.31 \pm 0.06^{\mathrm{cA}}$ \\
\hline & \multirow{2}{*}{$\begin{array}{c}\mathrm{AQE}\left(\mu \mathrm{mol} \mathrm{CO} \mathrm{CO}_{2} / \mu \mathrm{mol}\right. \\
\text { photon })\end{array}$} & Grazing & $0.046 \pm 0.001^{\mathrm{bB}}$ & $0.048 \pm 0.001^{\mathrm{aB}}$ & $0.045 \pm 0.001^{\mathrm{bB}}$ \\
\hline & & Fencing & $0.050 \pm 0.001^{\mathrm{bA}}$ & $0.055 \pm 0.001^{\mathrm{aA}}$ & $0.048 \pm 0.001^{\mathrm{cA}}$ \\
\hline & \multirow{2}{*}{$R_{\mathrm{D}}\left(\mu \mathrm{mol} \mathrm{CO} /\left(\mathrm{m}^{2} \cdot \mathrm{s}\right)\right)$} & Grazing & $0.982 \pm 0.019^{\mathrm{bB}}$ & $1.511 \pm 0.018^{\mathrm{aB}}$ & $0.886 \pm 0.043^{\mathrm{cB}}$ \\
\hline & & Fencing & $1.343 \pm 0.023^{\mathrm{bA}}$ & $1.791 \pm 0.087^{\mathrm{aA}}$ & $1.136 \pm 0.016^{\mathrm{cA}}$ \\
\hline & \multirow{2}{*}{$\mathrm{LCP}\left(\mu \mathrm{mol}\right.$ photon $\left./\left(\mathrm{m}^{2} \cdot \mathrm{s}\right)\right)$} & Grazing & $21.79 \pm 0.41^{\mathrm{bB}}$ & $32.99 \pm 0.47^{\mathrm{aB}}$ & $18.94 \pm 0.95^{\mathrm{cB}}$ \\
\hline & & Fencing & $29.83 \pm 0.87^{\mathrm{bA}}$ & $35.18 \pm 1.64^{\mathrm{aA}}$ & $24.33 \pm 0.57^{\mathrm{cA}}$ \\
\hline & \multirow{2}{*}{$\begin{array}{l}\operatorname{LSP}_{\text {obs }}(\mu \mathrm{mol} \\
\left.\text { photon } /\left(\mathrm{m}^{2} \cdot \mathrm{s}\right)\right)\end{array}$} & Grazing & $1405.40 \pm 7.10^{\mathrm{bB}}$ & $1498.50 \pm 4.40^{\mathrm{aB}}$ & $1388.30 \pm 5.40^{\mathrm{cB}}$ \\
\hline & & Fencing & $1500.40 \pm 0.64^{\mathrm{bA}}$ & $1542.90 \pm 5.70^{\mathrm{aA}}$ & $1441.00 \pm 6.40^{\mathrm{cA}}$ \\
\hline & \multirow{2}{*}{$R^{2}$} & Grazing & 0.998 & 0.999 & 0.997 \\
\hline & & Fencing & 0.999 & 0.999 & 0.999 \\
\hline
\end{tabular}

Note: $P_{\text {Nmaxobs}}$, observed maximum net photosynthetic rate; $P_{\text {Nmaxcal }}$, calculated maximum net photosynthetic rate; AQE, apparent quantum efficiency; $R_{\mathrm{D}}$, dark respiration; LCP, light compensation point; $\mathrm{LSP}_{\mathrm{obs}}$, light saturation point; The abbreviations are the same as in Table 6. Mean $\pm \mathrm{SD} ; n=6 . R^{2}$, coefficient of determination. Different uppercase letters mean significant differences for each parameter between two treatments on the same measuring date $(P<0.05)$. Different lowercase letters mean significant differences among different observation dates for the same treatment $(P<0.05)$.

\section{Discussion}

Grazing significantly decreased leaf gas exchange parameters (i.e., $P_{\mathrm{N}}, E$, and $g_{\mathrm{s}}$ ) and negatively affected the photosynthetic capacity in both $E$. nutans and $P$. anserina. Five years fencing significantly improved the photosynthetic capacity in both species. In addition, fencing increased the daily mean $P_{\mathrm{N}}$ values in both species, which is consistent with the previous research 
Table 6 Analysis of differences of parameters $\left(P_{\text {Nmaxobs }}, P_{\text {Nmaxcal }}, \mathrm{AQE}, R_{\mathrm{D}}, \mathrm{LCP}\right.$, and $\left.\mathrm{LSP}_{\mathrm{obs}}\right)$ in fencing plots

\begin{tabular}{|c|c|c|c|c|c|c|c|c|}
\hline Species & Treatment & Date & $P_{\text {Nmaxobs }} /(\mathrm{VR})$ & $P_{\text {Nmaxcal }}(\mathrm{VR})$ & AQE/(VR) & $R_{\mathrm{D}} /(\mathrm{VR})$ & $\mathrm{LCP} /(\mathrm{VR})$ & $\mathrm{LSP}_{\mathrm{obs}} /(\mathrm{VR})$ \\
\hline \multirow{4}{*}{ E. nutans } & \multirow{4}{*}{ Fencing } & 25 June & $* * /(25.0 \%)$ & $* * /(27.5 \%)$ & $* * /(9.7 \%)$ & $* * /(22.0 \%)$ & $* * /(17.6 \%)$ & $* * /(8.1 \%)$ \\
\hline & & 23 July & $* * /(13.6 \%)$ & $* * /(10.4 \%)$ & $* * /(3.7 \%)$ & $* * /(12.7 \%)$ & $* * /(10.7 \%)$ & $* * /(5.3 \%)$ \\
\hline & & 26 August & $* * /(40.8 \%)$ & $* * /(37.6 \%)$ & $* * /(23.6 \%)$ & $* * /(57.1 \%)$ & $* * /(31.8 \%)$ & $* * /(13.1 \%)$ \\
\hline & & Total & $* * /(26.5 \%)$ & $* * /(25.2 \%)$ & $* * /(12.4 \%)$ & $* * /(30.6 \%)$ & $* * /(20.1 \%)$ & $* * /(8.8 \%)$ \\
\hline \multirow{4}{*}{$\begin{array}{c}P . \\
\text { anserina }\end{array}$} & \multirow{4}{*}{ Fencing } & 25 June & $* * /(22.2 \%)$ & $* * /(32.5 \%)$ & $* * /(8.3 \%)$ & $* * /(36.8 \%)$ & $* * /(36.8 \%)$ & $* * /(6.7 \%)$ \\
\hline & & 23 July & $* * /(10.1 \%)$ & $* * /(14.2 \%)$ & $* * /(12.7 \%)$ & $* * /(18.5 \%)$ & $* /(6.6 \%)$ & $* * /(2.9 \%)$ \\
\hline & & 26 August & $* * /(20.6 \%)$ & $* * /(24.8 \%)$ & $* * /(6.3 \%)$ & $* * /(28.3 \%)$ & $* * /(28.4 \%)$ & $* * /(3.8 \%)$ \\
\hline & & Total & $* * /(17.6 \%)$ & $* * /(23.9 \%)$ & $* * /(9.1 \%)$ & $* * /(27.8 \%)$ & $* * /(23.9 \%)$ & $* * /(4.5 \%)$ \\
\hline
\end{tabular}

Note: * means significant difference at $P<0.05$ level; ** means significant difference at $P<0.01$ level. VR, variation ratio.

results (Zhang et al., 2009; Zlatev and Fernando, 2012; Tao et al., 2015; Ren et al., 2017). However, the patterns of $P_{\mathrm{N}}$ under both regimes varying across the three observation dates were different in $E$. nutans and $P$. anserina, which was likely attributed to the different adaptions of the two species. The higher $P_{\mathrm{N}}$ values of plants in fencing plots indicated that the appropriate protective measurement could improve the photosynthetic performance and alleviate the detrimental effects of grazing pressure (Zhao et al., 2008; Zhang et al., 2013; Liu et al., 2017). The second peak of $P_{\mathrm{N}}$, firstly discovered in our study area, appeared at approximately 17:30, which is inconsistent with previous results (Xiao et al., 2006; Liu et al., 2017), who reported that it occurred at approximately 14:00. Previous results indicated that "noon break" was related to the environmental factors (Jiang et al., 2010; Yang et al., 2016). Our result was different from those of other studies, and the difference may be attributed to the mountain environment with high temperature and high PAR during the period from 12:00 to 16:00. Our results showed that grazing significantly decreased $P_{\mathrm{N}}$. This result was consistent with the conclusion of Ghorbani et al. (2012), who reported that grazing decreased the carbon accumulation in mountainous arid and semi-arid rangelands. Fencing increased the daily mean values of $P_{\mathrm{N}}, P_{\text {Nmaxcal }}$, and $P_{\text {Nmaxobs }}$, showing that five years of fencing could enhance the potential photosynthetic capacity of $E$. nutans and P. anserina under natural conditions.

External stress could decrease the photosynthetic activity of plants by reducing carboxylation efficiency (e.g., stomatal closure and inhibiting light reaction) (Mudrik et al., 2003; Gu et al., 2017; Liu et al., 2017; Wang et al., 2017). The control of stomatal activity (i.e., transpiration, opening, and closure) is an active adaptive pattern of pasture species in response to environmental stress in semi-arid regions (Xoconostle-Cazares et al., 2010; Wu et al., 2015). Stomatal closure is the first response of grass species to external stress, such as mild to moderate drought stress. However, nonstomatal limitation factors dominate under severe drought stress (Flexas and Medrano, 2002; Jia et al., 2012; Wang et al., 2015; Abdi et al., 2016). Farquhar and Sharkey (1982) demonstrated that the stomatal factor is the dominant limiting factor of photosynthetic capacity only if $L_{\mathrm{s}}$ increases and $P_{\mathrm{N}}$ and $C_{\mathrm{i}}$ simultaneously decrease. Otherwise, nonstomatal factors are the limiting and dominant factors of photosynthetic capacity. In our study, the reduction in the $P_{\mathrm{N}}$ values of $P$. anserina under fencing and grazing conditions was caused by stomatal limitation. However, the decreases in the $P_{\mathrm{N}}$ and $L_{\mathrm{s}}$ of $E$. nutans were accompanied by an increase in $C_{\mathrm{i}}$ from 13:00 to 16:00, indicating that nonstomatal factors are the limiting factors for the photosynthetic capacity. The difference in the photosynthetic capacities of the two species might be caused by $g_{\mathrm{s}}$ and environmental factors. $P$. anserina has conspicuously higher $g_{\mathrm{s}}$ values than E. nutans, hence, $P$. anserina is less sensitive to external stress than E. nutans. Nonstomatal limitation for $E$. nutans during the period of 13:00 to 16:00 might be also caused by high air temperature and radiation. Some studies have shown that the change in $P_{\mathrm{N}}$ induced by stomatal limitation is often caused by environmental factors (Xia et al., 2015; Urban et al., 2017), and some studies pointed that extreme environmental factors might act as nonstomatal limitation factors for photosynthetic capacity (Borchard et al., 2015; Erel et al., 2015; Fu et al., 2015; Ramalhosa et al., 2017). 
WUE is an index of plant growth performance in the presence of any environmental constraint (Guo et al., 2011; Acuña et al., 2015; Elazab et al., 2016). In the study, the daily mean WUE of the two species was higher in fencing plot than in grazing plot. However, the variation in daily mean WUE for both plant species under fencing and grazing conditions was greater on 25 June and 26 August than on 23 July. This finding may be attributed to higher rainfall during July than other months. By comparing the WUE of the two species under both regimes, we inferred that grazing might affect photosynthetic capacity and subsequently affect the normal growth of grass.

The $P_{\mathrm{N}}$-PAR response curves of the plants were accurately fitted by the NRH with high $R^{2}$ values. Parameters were obtained from the fitted equations. AQE, an estimate of the maximum efficiency of light harvesting during $\mathrm{CO}_{2}$ assimilation (Linkosalo et al., 2016; Liu et al., 2017), was significantly higher in fencing plot than in grazing plot. And other parameters were also significantly increased under fencing treatment, which in turn improve the photosynthetic capability of the two species. Whereas, grazing significantly decreased the photosynthetic capability of herbages in study area.

$R_{\mathrm{D}}$ and LCP play critical roles in decreasing plant biomass accumulation in the individual, community, and ecosystem levels (Qiao et al., 2007; Zhang et al., 2015; Zhu et al., 2016). In our study, plants have higher $R_{\mathrm{D}}, \mathrm{LCP}$, and $\mathrm{LSP}_{\mathrm{obs}}$ in fencing plot than in grazing plot. The relative increases in $R_{\mathrm{D}}$ and LCP were smaller than that in $\mathrm{LSP}_{\text {obs }}$ in plants in fencing plot, indicating that fencing enhanced $\mathrm{CO}_{2}$ and $\mathrm{H}_{2} \mathrm{O}$ assimilations (Table 5). Thus, the increased assimilations could promote plant productivity and growth (Yin et al., 2006; Wu et al., 2008; Augé et al., 2015; Reef et al., 2015). This is consistent with our results that $P_{\mathrm{N}}$ was significantly higher in fencing plot than in grazing plot.

\section{Conclusions}

The diurnal patterns of leaf gas exchange parameters showed that five years of fencing significantly increased the photosynthetic parameters values of E. nutans and $P$. anserina, which increased the photosynthetic capacity. The enhanced effects were more sensitivity in $E$. nutans than $P$. anserina with five years of fencing, particularly at the end of the growing season. Hence, five years of fencing improved the potential photosynthetic capacity of both E. nutans and $P$. anserina. Our result provides a new insight in the grassland protection and gives grassland managers theory supporting for decision-making. However, our result should be further validated by data collected from different plant species that grow under different environments, particularly under environments that had been subjected to different periods of restricted grazing.

\section{Acknowledgements}

The research was financially supported by the National Natural Science Foundation of China (91025015, 51178209), and the Project of Arid Meteorological Science Research Foundation of China Meteorological Administration (IAM201608).

\section{References}

Abdi S, Abbaspur N, Avestan S, et al. 2016. Sana physiological responses of two grapevine (Vitis vinifera L.) cultivars to $\mathrm{Cycocel}^{\mathrm{TM}}$ treatment during drought. Journal of Horticultural Science and Biotechnology, 91(3): 211-219.

Acuña T B, Lisson S, Johnson P, et al. 2015. Yield and water-use efficiency of wheat in a high-rainfall environment. Crop and Pasture Science, 66(5): 419-429.

Andrew W, Jaime V, Alice B, et al. 2016. Past human disturbance effects upon biodiversity are greatest in the canopy: a case study on rainforest butterflies. PloS ONE, 11(3): e0150520.

Augé R M, Toler H D, Saxton A M. 2015. Arbuscular mycorrhizal symbiosis alters stomatal conductance of host plants more under drought than under amply watered conditions: a meta-analysis. Mycorrhiza, 25(1): 13-24.

Bai W, Fang Y, Zhou M, et al. 2015. Heavily intensified grazing reduces root production in an Inner Mongolia temperate steppe. Agriculture, Ecosystems \& Environment, 200: 143-150.

Borchard N, Schirrmann M, von Hebel C, et al. 2015. Spatio-temporal drivers of soil and ecosystem carbon fluxes at field scale 
in an upland grassland in Germany. Agriculture, Ecosystems \& Environment, 211(12): 84-93.

Calama R, Puértolas J, Madrigal G, et al. 2013. Modeling the environmental response of leaf net photosynthesis in Pinus pinea L. natural regeneration. Ecologcal Modelling, 251: 9-21.

Casazza M L, Overton C T, Bui T V D, et al. 2016. Endangered species management and ecosystem restoration: finding the common ground. Ecology and Society, 21(1): 19.

Chen S P, Bai Y F, Lin G H, et al. 2005. Effects of grazing on photosynthetic characteristics of major steppe species in the Xilin River Basin, Inner Mongolia, China. Photosynthetica, 43(4): 559-565.

Chesson P. 2000. Mechanisms of maintenance of species diversity. Annual Review of Ecology and Systematics, 31(1): 343-366.

Elazab A, Serret M D, Araus J L. 2016. Interactive effect of water and nitrogen regimes on plant growth, root traits and water status of old and modern durum wheat genotypes. Planta, 244(1): 125-144.

Erel R, Yermiyahu U, Ben-Gal A, et al. 2015. Modification of non-stomatal limitation and photoprotection due to K and Na nutrition of olive trees. Journal of Plant Physiology, 177: 1-10.

Farquhar G D, Sharkey T D. 1982. Stomatal conductance and photosynthesis. Annual Review of Plant Physiology, 33: 317-345.

Flexas J, Medrano H. 2002. Drought-inhibition of photosynthesis in $\mathrm{C}_{3}$ plants: stomatal and non-stomatal limitations revisited. Annals of Botany, 89(2): 183-189.

Fu G, Shen Z X, Sun W, et al. 2015. A meta-analysis of the effects of experimental warming on plant physiology and growth on the Tibetan Plateau. Journal of Plant Growth Regulation, 34(1): 57-65.

Ghorbani N, Raiesi F, Ghorbani S. 2012. Bulk soil and particle size-associated C and N under grazed and ungrazed regimes in Mountainous arid and semi-arid rangelands. Nutrient Cycling in Agroecosystems, 93(1): 15-34.

Gu J, Zhou Z, Li Z, et al. 2017. Rice (Oryza sativa L.) with reduced chlorophyll content exhibit higher photosynthetic rate and efficiency, improved canopy light distribution, and greater yields than normally pigmented plants. Field Crops Research, 200: 58-70.

Guo R Q, Ruan H, Yang W J, et al. 2011. Differential responses of leaf water-use efficiency and photosynthetic nitrogen-use efficiency to fertilization in Bt-introduced and conventional rice lines. Photosynthetica, 49(4): 507-514.

Guo S, Zhou Y, Shen Q, et al. 2007. Effect of ammonium and nitrate nutrition on some physiological processes in higher plants growth, photosynthesis, photorespiration, and water relations. Plant Biology, 9(1): 21-29.

Herrero-Jáuregui, C, Oesterheld, M. 2017. Effects of grazing intensity on plant richness and diversity: a meta-analysis. Oikos, 127(6): 757-766.

Hu Y K, Gao G G, Li K H, et al. 2009. The succession of plant communities in alpine grasslands in different ages of enclosing. Journal of Glaciology and Geocryology, 31(6): 1186-1194. (in Chinese)

Humphrey P T, Gloss A D, Alexandre N M, et al. 2016. Aversion and attraction to harmful plant secondary compounds jointly shape the foraging ecology of a specialist herbivore. Ecology and Evolution, 6(10): 3256-3268.

Jia K X, Wang Y Y, Sun W N, et al. 2012. Drought-responsive mechanisms in rice genotypes with contrasting drought tolerance during reproductive stage. Journal of Plant Physiology, 169(4): 336-344.

Jiang W W, Chen Y Q, Huang J R, et al. 2010. Photosynthetic characteristics with four cultivars of Aster novae-angliae. Journal of Zhejiang Forestry College, 25(8): 487-506. (in Chinese)

Jiao J Y, Zou H Y, Jia Y F, et al. 2009. Research progress on the effects of soil erosion on vegetation. Acta Ecologica Sinica, 29(2): 85-91. (in Chinese)

Linkosalo T, Elkhouri H, Mäkipää R, et al. 2016. Increased atmospheric $\mathrm{CO}_{2}$ concentration enhances the development of photosynthetic capacity beyond the temperature effect for silver birch in simulated future climate. Scandinavian Journal of Forest Research, 32(8): 651-657.

Liu C, Wang Y, Jin Y, et al. 2017. Photoprotection regulated by phosphorus application can improve photosynthetic performance and alleviate oxidative damage in dwarf bamboo subjected to water stress. Plant Physiology and Biochemistry, 118: 88-97.

Liu H, Zang R, Chen H Y H. 2016. Effects of grazing on photosynthetic features and soil respiration of rangelands in the Tianshan Mountains of Northwest China. Scientific Reports, 6: 30087.

Liu M, Gong J R, Pan Y, et al. 2016. Effects of grass-legume mixtures on the production and photosynthetic capacity of constructed grasslands in Inner Mongolia, China. Crop and Pasture Science, 67(11): 1188-1198.

Liu H, Fu Y, Wang M, et al. 2017. Green light enhances growth, photosynthetic pigments and $\mathrm{CO}_{2}$ assimilation efficiency of lettuce as revealed by 'knock-out' of the 480-560 nm spectral waveband. Photosynthetica, 55(1): 144-152.

Liu L, Guan L, Liu X. 2017. Directly estimating diurnal changes in GPP for $\mathrm{C}_{3}$ and $\mathrm{C}_{4}$ crops using far-red sun-induced chlorophyll fluorescence. Agricultural and Forest Meteorology, 232: 1-9.

Marshall B, Biscoe P V. 1980. A model for $\mathrm{C}_{3}$ leaves describing the dependence of net photosynthesis on Irradiance. I. 
Derivation. Journal of Experimental Botany, 31(1): 29-39.

Müller K, Dickhoefer U, Lin L, et al. 2014. Impact of grazing intensity on herbage quality, feed intake and live weight gain of sheep grazing on the steppe of Inner Mongolia. Journal of Agricultural Science, 152(1): 153-165.

Mekuria W. 2013. Changes in regulating ecosystem services following establishing exclosures on communal grazing lands in Ethiopia: a synthesis. Journal of Ecosystems, http://dx.doi.org/10.1155/2013/860736.

Mudrik V, Kosobrukhov A, Knyazeva I, et al. 2003. Changes in the photosynthetic characteristics of Plantago major plants caused by soil drought stress. Plant Growth Regulation, 40(1): 1-6.

Nijs I, Ferris R, Blum H. 1997. Stomatal regulation in a changing climate: A field study using free air temperature increase (FATL) and free air $\mathrm{CO}_{2}$ enrichment (FACE). Plant Cell and Environments, 20(8): 1041-1050.

Pei S, Fu H, Wan C. 2008. Changes in soil properties and vegetation following exclosure and grazing in degraded Alxa desert steppe of Inner Mongolia, China. Agriculture, Ecosystems \& Environment, 124(1-2): 33-39.

Prieto J A, Giorgi E G, Pena J P. 2010. Modelling photosynthetic-light response on Syrah leaves with different exposure. Vitis, 49(3): 145-146.

Pulido M, Schnabel S, Lozano-Parra J, et al. 2018. The impact of heavy grazing on soil quality and pasture production in rangelands of SW Spain. Land Degradation \& Development, 29(2): 219-230.

Qian J, Wang Z, Liu Z, et al. 2017. Belowground bud bank responses to grazing intensity in the Inner-Mongolia Steppe, China. Land Degradation \& Development, 28(3): 822-832.

Qiao Y Z, Zhang Y B, Wang K Y, et al. 2007. A new viewpoint to understand the response of leaf dark respiration to elevated $\mathrm{CO}_{2}$ concentration. Photosynthetica, 45: 510-514.

Ramalhosa P, Debus S L, Kaufmann M, et al. 2017. A non-native macroalga is less attractive for herbivores but more susceptible to light limitation and grazing stress than a comparable native species. Helgoland Marine Research, http://doi.org/10.1186/s10152-016-0478-3.

Reef R, Winter K, Morales J, et al. 2015. The effect of atmospheric carbon dioxide concentrations on the performance of the mangrove Avicennia germinans over a range of salinities. Physiologia Plantarum, 154(3): 358-368.

Ren H, Han G, Lan Z, et al. 2016. Grazing effects on herbage nutritive values depend on precipitation and growing season in Inner Mongolian Grassland. Journal of Plant Ecology, 9(6): 712-723.

Ren W, Hu N, Hou X, et al. 2017. Long-term overgrazing-induced memory decreases photosynthesis of clonal offspring in a perennial grassland plant. Frontiers in Plant Science, http://doi.org/10.3389/fpls.2017.00419.

Ruizalbarran M, Balocchi O, Wittwer F, et al. 2016. Milk production, grazing behavior and nutritional status of dairy cows grazing two herbage allowances during winter. Chilean Journal of Agricultural Research, 76(1): 34-39.

Shi F S, Wu Y, Wu N, et al. 2010. Different growth and physiological responses to experimental warming of two dominant plant species Elymus nutans and Potentilla anserina in an alpine meadow of the eastern Tibetan Plateau. Photosynthetica, 48(3): 437-445.

Singsaas E L, Ort D R, DeLucia E H. 2001. Variation in measured values of photosynthetic quantum yield in ecophysiological studies. Oecologia, 128(1): 15-23.

Strahan R T, Laughlin D C, Bakker J D, et al. 2015. Long-term protection from heavy livestock grazing affects ponderosa pine understory composition and functional traits. Rangeland Ecology \& Management, 68(3): 257-265.

Thornley J H M. 1998. Dynamic model of leaf photosynthesis with acclimation to light and nitrogen. Annals of Botany, 81(3): 421-430.

Urban J, Ingwers M W, Mcguire M A, et al. 2017. Increase in leaf temperature opens stomata and decouples net photosynthesis from stomatal conductance in Pinus taeda and Populus deltoides $x$ nigra. Journal of Experimental Botany, 68(7): 1757-1767.

Wang D, Wu G L, Liu Y, et al. 2015. Effects of grazing exclusion on $\mathrm{CO}_{2}$ fluxes in a steppe grassland on the Loess Plateau (China). Ecological Engineering, 83: 169-175.

Wang H, Prentice I C, Davis T W, et al. 2017. Photosynthetic responses to altitude: an explanation based on optimality principles. New Phytologist, 213(3): 976-982.

Wang Q L, Hua L M, Yang S W. 2014. Variation of grassland NDVI, climate factors and standing carrying capacity and their correlation in northern-Qilian Mountains from 1982 to 2006. Journal of Gansu Agricultural University, 49(4): 127-135. (in Chinese)

Wang X, Vignjevic M, Liu F, et al. 2015. Drought priming at vegetative growth stages improves tolerance to drought and heat stresses occurring during grain filling in spring wheat. Plant Growth Regulation, 75(3): 677-687.

Wang Y, Wesche K. 2016. Vegetation and soil responses to livestock grazing in Central Asian grasslands: a review of Chinese literature. Biodiversity and Conservation, 25(12): 2401-2420. 
Wertin T M, Reed S C, Belnap J. 2015. $\mathrm{C}_{3}$ and $\mathrm{C}_{4}$, plant responses to increased temperatures and altered monsoonal precipitation in a cool desert on the Colorado Plateau, USA. Oecologia, 177(4): 997-1013.

Wu F, Sheng P, Tan J, et al. 2015. Plasma membrane receptor-like kinase leaf panicle 2 acts downstream of the drought and salt tolerance transcription factor to regulate drought sensitivity in rice. Journal of Experimental Botany, 66(1): 271-281.

Wu F Z, Bao W K, Li F L, et al. 2008. Effects of water stress and nitrogen supply on leaf gas exchange and fluorescence parameters of Sophora davidii seedlings. Photosynthetica, 46(1): 40-48.

Xia J, Zhang S, Guo J, et al. 2015. Critical effects of gas exchange parameters in Tamarix chinensis Lour on soil water and its relevant environmental factors on a shell ridge island in China's Yellow River Delta. Ecological Engineering, 76: $36-46$.

Xiao A, Xu B, Liu J. 2006. A study on photosynthetic characteristics of Callistemon rigidus R. Br. Southwest Horticulture, 34(3): 19-20. (in Chinese)

Xu B C, Li F M, Shan L, et al. 2006. Gas exchange, biomass partition, and water relationships of three grass seedlings under water stress. Weed Biology and Management, 6(2): 79-88.

$\mathrm{Xu} \mathrm{B} \mathrm{C}, \mathrm{Xu} \mathrm{W}$ Z, Huang J, et al. 2011. Biomass production and relative competitiveness of a $\mathrm{C}_{3}$ legume and a $\mathrm{C}_{4}$ grass co-dominant in the semiarid Loess Plateau of China. Plant and Soil, 347(1-2): 25-39.

Yang S H, Wei J J, Ge H. 2016. The altitudinal effects on photosynthesis of Rosa platyacantha from the Tianshan Mountains in Northwestern China. Photosynthetica, 54(4): 572-580.

Yin C Y, Berninger F, Li C Y. 2006. Photosynthetic responses of Populus przewalski subjected to drought stress. Photosynthetica, 44(1): 62-68.

Zhang H, Gilbert B, Wang W, et al. 2013. Grazer exclusion alters plant spatial organization at multiple scales, increasing diversity. Ecology and Evolution, 3(10): 3604-3612.

Zhang Q, Zhang T J, Chow W S, et al. 2015. Photosynthetic characteristics and light energy conversions under different light environments in five tree species occupying dominant status at different stages of subtropical forest succession. Functional Plant Biology, 42(7): 1-9.

Zhang T, Zhang Y, Xu M, et al. 2015. Light-intensity grazing improves alpine meadow productivity and adaption to climate change on the Tibetan Plateau. Scientific Reports, 5: 15949.

Zhang Y L, Zhang H Z, Feng G Y, et al. 2009. Leaf diaheliotropic movement can improve carbon gain and water use efficiency and not intensify photoinhibition in upland cotton (Gossypium hirsutum L.). Photosynthetica, 47(4): 609-615.

Zhang Y P, Zhu X H, Ding H D, et al. 2013. Foliar application of 24-epibrassinolide alleviates high-temperature-induced inhibition of photosynthesis in seedlings of two melon cultivars. Photosynthetica, 51(3): 341-349.

Zhao C, Gao J, Huang Y, et al. 2017. The contribution of Astragalus adsurgens roots and canopy to water erosion control in the water-wind crisscrossed erosion region of the Loess Plateau, China. Land Degradation \& Development, 28(1): $265-273$.

Zhao W Y, Xu S, Li J L, et al. 2008. Effects of foliar application of nitrogen on the photosynthetic performance and growth of two fescue cultivars under heat stress. Biologia Plantarum, 52(1): 113-116.

Zhu S D, Li R H, Song J, et al. 2016. Different leaf cost-benefit strategies of ferns distributed in contrasting light habitats of sub-tropical forests. Annals of Botany, 117(3): 497-506.

Zlatev Z, Fernando C L. 2012. An overview on drought induced changes in plant growth, water relations and photosynthesis. Emirates Journal of Food \& Agriculture, 24(1): 520-524. 